\title{
THE EFFECT OF APPLYING THE INTERNATIONAL GUIDELINES FOR CLEAN SURGERY ON INFECTION CONTROL OF PATIENT'S CLOSE INTIMATE ENVIRONMENTS
}

\author{
Ismaeil Mohammed Abdulkahar ${ }^{a}$, Haider N. Mohammed ${ }^{\mathrm{b}, *}$, and Sabeeha Abdulla Mansour ${ }^{\mathrm{c}}$ \\ a Dept. of Medical Laboratories, College of Health Sciences, University of Duhok, Kurdistan Region, Iraq \\ ${ }^{b}$ Dept. of Anesthesia, College of Health Sciences, University of Duhok, Kurdistan Region, Iraq - haider_june@ hotmail.com \\ ${ }^{c}$ Dept. of Microbiology, Azadi Teaching Hospital, Health directorate of Duhok, Kurdistan Region, Iraq
}

\begin{abstract}
:
Surgical site infections are the most common cause of hospital acquired nosocomial infections. To evaluate the effects of applying and following the international standard guidelines for clean surgery on the final infection control in operation theatres, a comparative study was designed and carried out during the period from May 2014 to February 2015, at two operating theatres, the general surgical and the gynaecological theatre at Azadi teaching hospital - Duhok city - Kurdistan region. A total number of 492 samples (swabs and settles plate) were taken from different sites of intimate contact with the patients, and were divided into two parts, pre (part I) and post (part II) samples. They were taken in a periodic day to day, and collected periodically three days of the week (Saturday -Monday- Wednesday) for a period of one month. Swabs were taken from different places were streaked on Blood and Mac-Conkey agar plates and incubated at $37^{\circ} \mathrm{C}$ under aerobic conditions for 24 hours. After incubation, the bacterial colonies were counted and diagnosed by Phoenix. The concentration of bacteria was expressed as colony forming units. The rates of bacterial contamination in places of close contact with patients of both theatres before the application of the WHO guidelines were as following: out of 348 samples collected from the surgical theatre in the first part; $105(30.1 \%)$ showed significant growth in comparison to $32 / 144(22.2 \%)$ that showed significant growth from the gynaecological theatre, while all samples in part II from the surgical theatre showed no significant growth that 100\%, in comparison to141/144(97.92\%) in the gynaecological theatre in the second part after application of the WHO guidelines. As a conclusion there are 3 factors which have an effect on the result of surgical site infections namely patients, staff and environmental factors. The environmental factors have the greatest impact which are indirectly related to the degree of application of WHO standards of operation theatres.
\end{abstract}

KEYWORDS: Contamination, Operation theatres, International Guideline for Clean Surgery, Infection Control, Sterilization programme.

\section{INTERODUCTION}

The health-care environment contains a diverse population of microorganisms, but only a few are significant pathogens for susceptible humans. Microorganisms are present in great numbers in moist organic environments, but some also can persist under dry conditions. Although pathogenic microorganisms can be detected in air, water and on fomites, assessing their role in causing infection and disease is difficult. Only a few reports clearly delineate a "cause and effect" with respect to the environment and in particular, housekeeping surfaces (Sehulster et al., 2003).

Surgical site infections (SSIs) are the most common cause of hospital acquired nosocomial infections. These complications of surgical procedures can cause considerable morbidity, which may be raised to mortality as high as $77 \%$ if it occurs at deep tissue. The source of SSIs may be endogenous (normal flora of the patient's skin, mucous membranes or viscera) or exogenous, which includes surgical personnel (especially members of the surgical team), the surgical room environment (air, floor \& wall), tools, instruments and materials brought to the sterile field during surgery. By maintaining sterile environment in surgical

\footnotetext{
* Corresponding author
}

theatres we can control a major part of exogenous infections (OTSF, 2009).

Optimum infection prevention and control in the operation theatres is essential to ensure that patients who undergo any surgical procedure receive safe and effective care. The standard required for the fabric of the theatre environment is addressed in the policy for microbiological air sampling of operating theatres. This policy considers the practices in a working operating department. The needs of children and young people have been considered in relation to this policy and the principles of this policy apply equally to children and young people across the trust. Effective infection prevention and control must be part of everyday practice and be applied consistently by everyone. Safe working practices must be followed for all patients regardless of known or suspected infection. The principle upon which this practice is based is that of 'Standard Precautions'. Blood and body fluids of all patients must be considered potentially hazardous for blood borne viruses. All patients have the right to be treated with dignity and respect and the use of standard precautions eliminates the risk of random inappropriate practice and permits staff to deliver high standards of care to all patients at all times ( Lishman et al., 2013).

The importance of a clean-safe environment for all aspects of healthcare should not be underestimated. It is important that 
healthcare buildings are designed with appropriate consultation and the design facilitates good infection prevention and control practices (Lishman et al., 2013). Good standards of basic hygiene, cleaning and regular planned maintenance will assist in preventing healthcare-associated infection (HCAI), as well it will reduce contamination and risks to patients (DHEF, 2013).

Researches and investigations have consistently confirmed that the healthcare environment can be a reservoir for organisms with the potential for infecting patients. For HCAIs to be reduced, it is imperative that Infection Prevention and Control (IPC) measures are "designed-in" at the very outset of the planning and design stages of a healthcare facility and that input continues up to, into and beyond the final building stage. Designed in IPC means that both groups first of (designers, architects, engineers, facilities managers and planners) should work in collaborative partnership with second group of (IPC teams, healthcare staff and the users) in order to deliver facilities in which needs of IPC have been anticipated, planned for and met (DHEF, 2013).

The current study was initiated, in order to answer the inquiry of the General Manager of Azadi Teaching Hospital about the location of the missing circles of the infection control chain in the operation theatres, causes of and solutions for the high incidence of SSIs that appeared in their hospital despite the present sterilization measures. The present study was Planed in Azadi teaching hospital, after the appearance of many postoperative infection cases, These inquiries were referred to the college of medicine to investigate the situation in their hospital operation theatres, for which this project was proposed and it was approved by the College Scientific Academic Committee and aimed to:

1. Determine the extent of microbial contamination in the OTs which could be the common causes of SSI in Azadi Teaching Hospital.

2. Determine the effect of sterilization duration and its frequency throughout the week on microbial growth.

3. Ascertain the deficiency in the sterilization programme that was used in operation theatres.

4. Determine the differences in microbial growth after applying some of the missing items in sterilizing programme.

5. Evaluate the effects of applying and following the international standard guidelines for clean surgery on the final infection control in operation theatres.

\section{MATERIALS AND METHODS}

\subsection{Area of Study}

This study was conducted in Azadi Teaching Hospital Duhok during the period from May 2014 to February 2015 at two operating theatres: the general surgical operation theatre and the gynaecological operation theatre.

\subsection{Collection of samples from operational lounges}

Samples were collected periodically (Settle plate and swabs) three days a week (Saturday -Monday- Wednesday) for a period of one month for each lounge operation. This means that each of the sites in question was sampled 12 times at least.
The general surgery operation theatre contains five operation rooms; whereas the gynaecology's operation theatre consists of two rooms.

All samples (Settle plate and swabs) were taken by frequency of 12 for each item wherever it was present in individual operating rooms.

\subsection{Methods of sampling}

The evaluation of bacterial contamination in an operating theater was performed by using the settle plate and swab methods.

2.3.1 The settle plate method: Air sampling was performed with settle plate methods according to Javed et al (2008); Napoli et al (2012); Singh et al (2013). Petri dishes containing Nutrient, Blood and MacConkey agar media were transported to operation theatres in sealed plastic bags. The plates were labeled with a number, site within the theatre, time and date of sample collection. The plates were placed at four chosen corner places in each room in the operation theatres at about 1 meter above the ground, and were exposed for 25-30 minutes. After this exposure, the plates were covered with their lids and taken to the laboratory in sealed plastic bags and incubated at $37^{\circ} \mathrm{C}$ for 24 hours.

2.3.2 The swab method: Swab soaked in nutrient broth were used to collect samples from the floor, walls, equipment, instruments, operation tables, wash basin etc. (Landrin et al., 2005; Singh et al., 2013). All the taken samples were labeled properly and immediately transported to the microbiology department of Azadi Teaching Hospital for processing. The processing of samples was done after Singh et al., (2013).The swabs were taken from different places and were streaked on Blood and Mac-Conkey agar plates. These culture plates along with those exposed to air were incubated at $37^{\circ} \mathrm{C}$ under aerobic conditions for $24 \mathrm{hrs}$. After incubation, the colonies were counted and identification of isolates was performed by phoenix BD. The concentration of airborne bacteria was expressed as colony forming units per cubic meter (cfu /m3).

\subsection{Culturing of samples}

The collected samples from different places were cultured on Blood and MacConkey agar media (table 2). These culture plates along with those exposed to air were incubated at $37^{\circ} \mathrm{C}$ under aerobic conditions for $24 \mathrm{hrs}$. After incubation the colonies were counted and isolates were identified. The concentration of bacteria was expressed as colony forming units per cubic meter (cfu/ $\left.\mathrm{m}^{3}\right)$, after Ensayef et al. (2009) and Desai et al. (2012). The collected samples were cultured within 1 hour using standard bacteriological inoculation techniques.

\subsection{Significance of the colony numbers}

2.5.1 Air: The numbers of colony forming units per cubic meter in the operation theatres should be less than $1.0 \mathrm{cfu} / \mathrm{m}^{3}$ in the center of an empty theatre and less than $10 \mathrm{cfu} / \mathrm{m}^{3}$ during an operation, and should not exceed $20 \mathrm{cfu} / \mathrm{m}^{3}$ at the periphery (Javed et al., 2008). With respect to airborne bacterial concentration in a modern ventilated operating room should not exceed $30 \mathrm{cfu} / \mathrm{m}^{3}$ (William et al., 2008). 
2.5.2 Environmental surface samples: The colony count causing SSI was estimated by $>10^{5} \mathrm{cfu} / \mathrm{m}^{2}$ for the purpose of evaluation of contamination this level was considered significant risk factor for infection at OT( Baillie et al., 2008; WHO., 2009 and Desai et al., 2012).

\subsection{Scheduling the data}

The obtained data were scheduled as following:

a. The data were scheduled according to significant and non-significant growth before including the WHO guideline in research in surgery and gynaecology OTs.

b. The significant and non-significant growth after including the WHO guideline in research in surgery and gynaecology OTs.

Table 1. Check list table applied to the surgery and the gynaecology operation theatres.

\begin{tabular}{|c|c|c|}
\hline No. & $\begin{array}{l}\text { Operational } \\
\text { Lounge }\end{array}$ & Staff Behaviour and screening \\
\hline 1. & $\begin{array}{l}\text { Traffic and suite } \\
\text { zones }\end{array}$ & $\begin{array}{l}\text { 1-Open zone } \\
\text { 2-Dirty zone } \\
\text { 3-Corridor } \\
\text { 4-Recovery room } \\
\text { 5-Storeage room } \\
\text { 6-Bathroom } \\
\text { 7-Sink }\end{array}$ \\
\hline 2. & $\begin{array}{l}\text { Housekeeping } \\
\text { and general } \\
\text { cleaning methods }\end{array}$ & $\begin{array}{l}\text { The system of cleaning that is } \\
\text { followed by employees } \\
\text { 1-After each single operation } \\
\text { 2-At the end of a working day } \\
\text { 3-At the end of fumigation day } \\
\text { 4- type of sterilizers used in OT }\end{array}$ \\
\hline 3. & Scrubbing unit & No written policy or procedures \\
\hline 4. & $\begin{array}{l}\text { Sterilization } \\
\text { System }\end{array}$ & $\begin{array}{l}\text { Surgical Instrument good disinfected } \\
\text { Disinfection once per week }\end{array}$ \\
\hline 5. & Laundry & Surgical Gowns \\
\hline 6. & $\begin{array}{l}\text { Environmental } \\
\text { and surface check } \\
\text { for contamination }\end{array}$ & $\begin{array}{l}\text { 1-Air } \\
\text { 2-Ventilator Filters } \\
\text { 3-Anaesthesia Units } \\
\text { anaesthetic mask, anaesthesia drug } \\
\text { trolley, anaesthesia machine, } \\
\text { monitor, scope monitor, sucker, } \\
\text { ventilator } \\
\text { 4- Surfaces and articles in contact } \\
\text { with patients (endoscope) } \\
\text { 5-Surgical tool and instruments } \\
\text { cautary, } \\
\text { laryngoscope, } \\
\text { Oesophagogastrodudenoscope } \\
\text { Uroscopes tools, } \\
\text { 6- walls, floor, sink, } \\
\text { 7- Surgical light, patient table, } \\
\text { counter surfaces }\end{array}$ \\
\hline 7. & $\begin{array}{l}\text { Screening } \\
\text { medical staff of } \\
\text { MRSA }\end{array}$ & $\begin{array}{l}\text { Doctors - Nurses and janitors } \\
\text { Take two } \\
\begin{array}{cl}1- & \text { Nasabs from all } \\
2- & \text { Under nail after washing }\end{array}\end{array}$ \\
\hline
\end{tabular}

\subsection{Statistical analysis}

The data were entered into Microsoft Excel (2010), and then converted to SPSS 22 (2013) for manipulation and analysis. Tables were constructed to describe the data, frequency and frequency percentage, then means standard diffusions, were calculated. Numerical were analyzed by Paired-sample T Test, Pvalue $<0.05$ was used to indicate statistical significance. This study was carried out in two stages:

2.7.1 Part I: Pre-assessment and observational stages: This stage included a periodic day-to-day observation and recording of the routine work and the precision in the application of the infection control standards scheme currently followed at the OTs by the infection control committee at Azadi Teaching Hospital according to a prepared check list (Table 1), (NTNHS Hospitals Foundation Trust (2013)).

This observational study was supported by a bacteriological surveillance to act as a tool to estimate the level of microbial contamination risk in OTs.

The bacteriological surveillance included sampling from different sites which divided into three group (A, B and C) according to the distance from patient (Table 2) like air, surfaces and surgical equipment in OTs involved in exposure to the patient and the operating staff. (Mangram et al., 1999; Bruce et al., 2001; William et al., 2008; Baillie et al., 2008; WHO, 2009; Merican et al., 2009; Desai et al., 2012)

For the purpose of this study, the evaluation of the precision of application was compared to the National Standard Guidelines of WHO, to act as a golden standard (WHO Guidelines for Infection Control, 2009).

This investigation led to specify and pinpoint some present pitfalls in designs, rituals and behaviours at the OTs. The current infection control standards at Azadi Teaching Hospital were upgraded according to the WHO infection control guidelines after being approved by the infection control committee; new trends and changes were applied according to the finance and design. The total number of samples taken was 492, each part of 246 samples and each site was sampled in the same rate and frequency in pre and post assessment study.

Table 2. Distribution of data to three groups (A, B and C).

\begin{tabular}{|c|c|c|}
\hline Group & Site & $\begin{array}{c}\text { Bacterial } \\
\text { colony count }\end{array}$ \\
\hline $\begin{array}{l}\text { Group } \\
\text { A }\end{array}$ & $\begin{array}{l}\text { Intimate contact with patient } \\
\text { (Air, Filter, Cautry., Gauze drum, } \\
\text { Surgical Instrument, Surgeon } \\
\text { clothes) }\end{array}$ & $\begin{array}{ll}\text { Should } & \text { be } \\
\text { sterile } & (0) \\
\mathrm{cfu} / \mathrm{m}^{3} & \end{array}$ \\
\hline $\begin{array}{l}\text { Group } \\
\text { B }\end{array}$ & $\begin{array}{l}\text { Nearby patient (Patient table, } \\
\text { Ventilator, Mask Anaesthesia, } \\
\text { ENT. Light Laryngoscope, } \\
\text { Sucker, OGD, Laparoscope) }\end{array}$ & $\begin{array}{lr}{ }^{*} \text { Small } & \text { number } \\
\text { of } & \text { bacterial } \\
\text { colony } & \text { count } \\
\text { cfu/ } \mathrm{m}^{2} & \\
\end{array}$ \\
\hline $\begin{array}{l}\text { Group } \\
\text { C }\end{array}$ & $\begin{array}{l}\text { Far away from patient (Floor, } \\
\text { Wall, Anaesthesia table, Monitor. } \\
\text { Scopemontior, Anaesthesia drug } \\
\text { trolley, Zones, Sink. Bathroom) }\end{array}$ & $<10^{5} \mathrm{cfu} / \mathrm{m}^{2}$ \\
\hline
\end{tabular}

2.7.2 Part II- Post assessment stage: A second bacteriological surveillance from the same sites was performed after upgrading (staff were excluded).

\subsection{Identification of causes.}

The causes of the above positive samples were identified after obtaining part one result according to Newcastle upon Tyne NHS Hospitals Foundation Trust (2013). It was listed in official letter for the general manager of Azadi teaching hospital. As following (concerning the group A materials):

The suggestions of the post first samples collection to the hospital administration

\subsubsection{Gynaecological Rooms}

1. Rooms Air: Note the bacterial growth on blood agar appeared on the Wednesday (end of the week) after accumulations of bacteria and finishing of the effect 
of Thursday sterilization. The sterilization procedure is suggested to be twice a week.

2. Cautary table: No bacterial growth means good cleaning and disinfection of the cautary table. No need to do anything but ensure them.

3. Gauze drum: No bacterial growth which means that the sterilization system used for gauze drum is perfect.

4. Air conditioning filter 1: The bacterial growth from the filter1 is decreased mildly by air sterilization. This filter must be replaced or cleaned at the end of week (Wednesday).

5. Air conditioning filter 2: The bacterial growth from the filter2 is mildly decreased by air sterilization. This filter must be replaced or cleaned at the end of week (Wednesday).

6. Laparoscope tools: No growth has been collected in the laparoscopic tools. Means good disinfectant strategy.

\subsubsection{General Surgery Rooms}

1. Rooms Air: The bacterial growth appeared just on the end of working week (Wednesday) after accumulation of bacteria and finishing of the effect of Thursday sterilization. The suggestion is to make sterilization twice weekly.

2. Cautary table: $10 \%$ bacteria growth concentrated on end of working weeks (Wednesday) that means cleaning and disinfection of the cautary table is not enough. The suggestion is to follow their work and ensure them.

3. Gauze drum: There was significant bacterial growth which means misuse of the drum without taking care of the precautions of contamination during gauze taking meanwhile we can guarantee that the sterilization system used for gauze drum is perfect because it is the same of the surgical instruments. The suggestion for staff is to be more careful when dealing with the drum or use small drums that will finished in one day.

4. Air conditioning filter 1: The bacterial growth from the filter 1 is decreased mildly by air sterilization. The suggestion is to replace or clean of the filter at the end of working day.

5. Air conditioning filter 2: The bacterial growth from the filter2 is decreased mildly by air sterilization. The suggestion is to replace or clean this filter at the end of day.

6. Laparoscope tools: Few bacterial growths in the second week only in room 1 of course because the laparoscope is only in room1.The suggestion is to instruct the staff to follow the international guide lines in cleaning and disinfecting.
7. ENT Laryngoscope: The bacterial growth decreased mainly in the first working days (Saturday) in first 2 weeks in rooms $1 \& 2$ while in other rooms there is no laryngoscope. This means the staff that responsible for the cleaning and disinfection of this instruments, are not following the international guide line. The suggestion is to instruct them about the cleaning and disinfection.

8. Oesophageogastroscope: Few growths in the second week only in room 1 of course because the OGD is only in room 1.The suggestion is to instruct the staff how to follow the international guide lines of cleaning after working day.

2.9 2.9 The hospital applies some of WHO guidelines according to the following:

After reviewing the results and suggestions through a presentation made at Azadi Teaching Hospital, in presence of the administrative board of the hospital and a number of surgeons and Heads of departments after deliberation, they agreed that some changes could fix the existing problem of nasocomial infection in OTs. Here are the changes that took place in the OTs especially in the surgery, meanwhile in the gynecology operation theaters, there were less changes due to the difficulty that happened.

1. Disinfection of operation room was changed from once a week on (Thursdays only) to twice a week on (Monday \& Thursday) in the operation theaters.

2. Changed of the air filters of the operation rooms.

3. Establishment of the corridor of the dirty zone.

4. Daily disinfection of operation rooms number

5. Separation of bathrooms shoes from operation room shoes.

2.10 2.10 The steps in 2.2 to 2.7 were repeated after the hospital application of 2.9 .

2.11 The statistical analysis was done according to student $\mathbf{t}$ test between the positive result in 2.7 and 2.9 (before and after the application of the international WHO guidelines).

\section{RESULTS}

Table 3 shows that out of 174 samples taken from the surgical theatre in the first part, $60.34 \%(105 / 174)$ of them showed significant growth (according to 2.6), in comparison to $44.4 \%$ (32/72) taken from gynaecological theatre showed significant growth. While in the second part (after the application of WHO guideline) $100 \%$ of the sample of the Surgery operation theatre and $95.8 \%$ of the gynaecological theatre did not show any significant growth of microorganisms.

Table 3. Significant and non-significant growth before and after application of WHO guideline group (A) in surgery and gynaecology OTs

\begin{tabular}{|c|c|c|c|c|c|}
\hline \multirow{3}{*}{ Site Group A } & \multirow{3}{*}{$\begin{array}{c}\text { Number of collected } \\
\text { sample }\end{array}$} & \multicolumn{2}{|c|}{ Before } & \multicolumn{2}{|c|}{ After } \\
\hline & & $\begin{array}{l}\text { Significant } \\
\text { growth }\end{array}$ & $\begin{array}{l}\text { Non-significant } \\
\text { growth }\end{array}$ & $\begin{array}{l}\text { Significant } \\
\text { growth }\end{array}$ & $\begin{array}{c}\text { Non- } \\
\text { significant } \\
\text { growth }\end{array}$ \\
\hline & & No $(\%)$ & No $(\%)$ & No $(\%)$ & No $(\%)$ \\
\hline Surgery operation theatre & 348 & $105(60.34 \%)$ & $\begin{array}{c}69 \\
(39.6 \%)\end{array}$ & 0 & $\begin{array}{c}174 \\
(100 \%)\end{array}$ \\
\hline $\begin{array}{l}\text { Gynaecology operation } \\
\text { theatre }\end{array}$ & 144 & $\begin{array}{c}32 \\
(44.4 \%)\end{array}$ & $\begin{array}{c}40 \\
(55.6 \%)\end{array}$ & $\begin{array}{c}3 \\
(4.2 \%)\end{array}$ & $\begin{array}{c}69 \\
(95.8 \%)\end{array}$ \\
\hline Total & 492 & 137 & 181 & 3 & 243 \\
\hline
\end{tabular}


As indicated from Table 4, the mean number of the isolated bacteria was the least on Saturday (3.55) and increased from 15.75 to 35.75 folds on Monday and Wednesday before the application of WHO guideline, but after their application became $0 \%$ in all the tested days.

Similar pattern of mean bacterial colony count was observed in Gynaecology Theatre before the application of WHO guidelines (Table 5). While after the application of the guidelines only on Saturday a mean number of 1.395 colonies were recorded, regarding other days also no colonies were detected.

Table 4. Group A colony count for bacterial isolates before and after application and $\mathrm{P}$-value on different days in the surgical OTs. (No. of collected samples $=116$ for each day).

\begin{tabular}{|c|c|c|c|}
\hline Group A & $\begin{array}{c}\text { Bacterial } \\
\text { isolates - } \\
\text { Refore }\end{array}$ & $\begin{array}{c}\text { Bacterial } \\
\text { isolates- After }\end{array}$ & P- \\
\hline Day & $\begin{array}{c}\text { Colony count } \\
\text { Mean } \\
\text { (SD) } \\
\end{array}$ & $\begin{array}{c}\text { Colony count } \\
\text { Mean } \\
\text { (SD) } \\
\end{array}$ & value* \\
\hline Saturday & $\begin{array}{c}3.55 \\
(11.419)\end{array}$ & $\begin{array}{c}0.000 \\
(0.000)\end{array}$ & $<0.001$ \\
\hline Monday & $\begin{array}{c}15.75 \\
(33.547)\end{array}$ & $\begin{array}{c}0.00 \\
(0.000)\end{array}$ & $<0.001$ \\
\hline Wednesday & $\begin{array}{c}35.75 \\
(104.776)\end{array}$ & $\begin{array}{c}0.000 \\
(0.000)\end{array}$ & $<0.001$ \\
\hline
\end{tabular}

*According to Paired-sample T Test.

Table 5. Group A colony count for bacterial isolates before and after application and $\mathrm{P}$-value on different days in the gynaecology OTs. (No. Of collected samples $=48$ for each day)

\begin{tabular}{|c|c|c|c|}
\hline Group A & $\begin{array}{c}\text { Bacterial } \\
\text { isolates - } \\
\text { Before } \\
\end{array}$ & $\begin{array}{c}\text { Bacterial } \\
\text { isolates- After }\end{array}$ & P- \\
\hline Day & $\begin{array}{c}\text { Colony count } \\
\text { mean } \\
(\mathrm{SD}) \\
\end{array}$ & $\begin{array}{c}\text { Colony count } \\
\text { mean } \\
(\mathrm{SD}) \\
\end{array}$ & value* \\
\hline Saturday & $\begin{array}{c}1.687 \\
(8.308)\end{array}$ & $\begin{array}{c}1.395 \\
(5.487)\end{array}$ & 0.722 \\
\hline Monday & $\begin{array}{c}6.437 \\
(14.957)\end{array}$ & $\begin{array}{c}0.000 \\
(0.000)\end{array}$ & $<0.001$ \\
\hline Wednesday & $\begin{array}{c}18.458 \\
(31.452)\end{array}$ & $\begin{array}{c}0.000 \\
(0.000)\end{array}$ & $<0.001$ \\
\hline
\end{tabular}

*According to Paired-sample T Test

\section{DISCUSSION}

This study is composed of two parts, both of which assessed the microbial contamination in operation theatres. However, the difference between them is that in the first part, the theatres were examined as they are, while in the second one the same theatres were examined after making some changes according to the direction for application of some of the WHO guidelines in the operation theatres.

Due to the scarcity of the information in this direction in Kurdistan, Iraq and surrounding countries it is impossible to compare the result, however, there are few studies such as, microbiological contamination in the operation room is generally considered to be a risk factor for surgical site infections (Landrin et al., 2005).

In the current study the percentage of contaminations in part $\mathrm{I}$, before the application of the guidelines in the general surgery operation theatre, was $63.2 \%$. This percentage is higher than a study performed by Ibraheem et al (2009) in Al- Hilla hospitals in Iraq in which they recorded $32.85 \%$ contamination and stated that this may be attributed to many factors including the abuse of disinfectants or even the carelessness throughout the preparations. On the hand a much higher rate $(85.9 \%)$ was reported in Nigeria by Okon et al., (2012). In part II of the study after the application of some of WHO guidelines, the contamination rate dropped to $0.0 \%$, this rate is perfect as compared with other studies performed in some country such as that performed by Vincent et al. (1995) in which they recorded rates of 19, 6.7 and 14\% in intensive care unit patient in Italy, France and Switzerland, respectively. The finding of the current study is suggestive of many factors including that the healthcare system in Azadi Teaching Hospital is still not following the rules of infection control system, since the WHO standards are not precisely applied in the operation theatres.

On the other hand, the current study has revealed that the decrease in the contamination rates, after the application of some of the WHO guidelines may be due to the active dirty zone, frequent changes of air filters, rest room shoes changing and fumigation which is done twice weekly. These results are similar to those of Suzuki et al (1984), who stated that activating dirty zone reduce the bacterial surface contamination on floors in operating theatres. On the other hand, Tesfaye et al (2015) stated that fumigation significantly reduced the microbial contamination, and the bacterial strains, of operating theatre.

In the present study, the contamination rates in the gynaecological theatre was $44.4 \%$ which is slightly lower as compared with a study conducted in Nigeria by Nwankwo (2012), which was $50.8 \%$. This may be due to the gynaecology ward condition, which receive a higher number of patients and more emergencies.

The bacteria growth increased significantly with the working days along the week in part I (Saturday to Monday to Wednesday) and this was true for all locations of the operation theatre regardless to the distance from the patient. While in part II, the bacterial growth was reported on Monday only in the surgical operation rooms but it was lesser than the growth on the same day in part I. The sharp fall in bacterial growth generally can be explained by applying some WHO guidelines. The highest growth in Monday, could be due to the crowding, as large number of operations were performed on this day, and also to the longest interval from the last fumigation compared with other sampling days (Saturday and Wednesday), This indicate that the fumigation has become more sufficient in part II (every Monday and Thursday). With respect to the gynaecological theatre these changes were not performed, because there is no such dirty zone in the gynaecology theatre, and air filters were not changed. Therefore, only fumigation was performed in gynaecology OTs according to the accordance of the WHO standards of such theatres.

The significant difference in the bacterial load between the two parts (I and II) of the current study reflects the application of some standards of WHO in Azadi Teaching Hospital theatres.

\section{CONCLUSION}

From the present study it was concluded that in operation theatres there are 3 factors that result in SSI namely: patient, staff and the environment. The environment has the most serious impact and is indirectly related to the extent of application of WHO standards of operation theatre. In addition to the application of some of the above standards made a big difference, especially on the objects in intimate and close contacts with the patient; impact was less 
on objects that are not in contact to the patient. Also the application of more WHO standards had the greater decrease in the number of isolated colonies in the operation theatres. Therefore, the application of WHO standards for clean surgery are strongly recommended to overcome these problems.

\section{REFERENCES}

Baillie, N.; Crawshaw, S.; Neary, R.; Smith, T.; Bee, C.; Clifford, E.; et al (2008). Prevention and Treatment of Surgical Site Infection NICE Clinical Guidelines. Health Guidance in UK. NICE quality standard, 49:22-5

Bruce, J.; Russell, E.M.; Mollison, J.; Krukowski, Z.H. (2001). The measurement and monitoring of surgical adverse events. Health Technology Assessment, 5(22):1-194.

Department of Health Estates and Facilities (2013). Health Building Note 00-09: Infection control in the built environment, ENG. Department of Health (guidance): 11-29.

Desai, S. N.; Kikani, K. M.; Mehta, S. (2012). Microbilogical Surveillance of Operation Theaters \& Intensive Care Units of Teaching Hospital in Surendranagar. Gujarat Medical Journal, 67(2):95-97.

Ensayef, 1. S.; Al-Shalchi, S.; Sabbar, M. (2009). Microbial contamination in the operating theatre: a study in a hospital in Baghdad. Eastern Mediterranean Health Journal, 15(1): 219-23.

Ibraheem, H. H.; Wesam, A.Z.; Hindi, B. H.; ALamedi. S.; Shorok, A. A.; AL Ameer, D. etal (2009). Bactriological Study of Nosocomial Infections Caused by Aerobic Bacteria in Hilla General Hospital. Al Taqani, 22(4):1-5.

Javed, I.; Hafeez, R.; Zubair, M.; Anwar, M.S.; Husnain, S. (2008). Microbiological surveillance of operation theatres and ICUs of a tertiary hospital. Lahore Biomedica, 24(1): 102- 99

Landrin, A.; Bissery, A.; Kac, G. (2005). Monitoring air sampling in operating theatres: can particle counting replace microbiological sampling. Journal of Hospital Infection, 61 (1):9- 27

Lishman, G.; Robb, A.; Winter, C.; Matron, J, L. (2013). Infection Prevention and Control Practice in the Operating Department. Ratified by: Infection Prevention and Control Committee, 3(1):1-12.

Mangram, A.J.; Horan, T.C.; Pearson, M.L.; Silver, L.C.; Jarvis, W.R. (1999) Guidelines for prevention of surgical site infection. Hospital Infection Control Practices Advisory Committee, 20(4): 251-75.

Merican, M. I.; Abdullah, N. H.; Maskon, K.; Zain, R. M.; Sutris, J. M. et al(2009).Policies And Procedures On Infection Control. Quality Medical Care Section .Text in Medical Development Division, Ministry of Health Malaysia. 2nd edition: 81-168.

Napoli, C.; Marcotrigiano, V.; Montagna, M.T.(2012).Air sampling procedures to evaluate microbial contamination: A comparison between active and passive methods in operating theaters. BioMedical Central Puplic health, 12(594):1-6.

Newcastle upon Tyne NHS Hospitals Foundation Trust (2013) Infection Prevention and Control Practice in the Operating Department, version No.3.1.

Nwankwo, E. (2012).Isolation of pathogenic bacteria from fomites in the operating rooms of a specialist hospital in Kano, North-western Nigeria. Pan African Medical Journal, 12(90): 1307-90

Okon, K. O.; Osundi, S.; Dibal, J.; Ngbale, T.; Bello, M.; Akuhwa, R.T. et al (2012). Bacterial contamination of operating theatre and other specialized care unit in a tertiary hospital in Northeastern Nigeria. African Journal of Microbiology Research, 6(13): 3092-6.

Operation Theatre Sterilization by Fumigation (2009). Infection Control; 15 comments. iNVISIBLE YET iNVINCIBLE . Published by Mas template.

Sehulster, 1.; Raymond, Y.W.; Hughes, J.M.; Solomon, S.L. et al (editor) (2003). Guidelines for Environmental Infection Control in Health-Care Facilities. Centers for Disease
Control and prevention "Morbidity and Mortality Weekly Report, 52 (10): 1- 48

Singh, K.; Dar, F. A.; Kishor, K. (2013). Bacterial Contamination Operating Theatres of District Hospital Budgam in Kashmir Division. Innovative Journal of Medical and Health Science, 3(2): $62-3$.

Suzuki, A.; Namba, Y.; Mastsuurat, M.; Horisawa, A. (1984). Bacterial contamination of floors and other surfaces in operating rooms: a five-year survey. Journal of hygiene .93(3): 559-566.

Tesfaye, T.; Berhe, Y.; Gebreselassie, K. (2015). Microbial contamination of operating Theatre at Ayder Referral Hospital, Northern Ethiopia. International Journal of Pharma Sciences and Research, 6 (10): 1264-67.

Vincent, J.R.; Bihari, D.J.; Suter, P.M. (1995).The prevalence of Nosocomial infection in intensive unit in Europe. Journal American medical association, 274(8): 639-644.

William, A.; Rutala, D.; David, J.; Weber, M.D. (2008). Guideline for Disinfection and Sterilization in Healthcare Facilities. Centers for Disease Control and prevention, 39(5): 702-709.

World Health Organization (WHO) (2009). Practical Guidelines for Infection Control in Health Care Facilities,Text :1-120. 


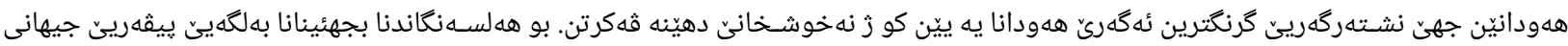

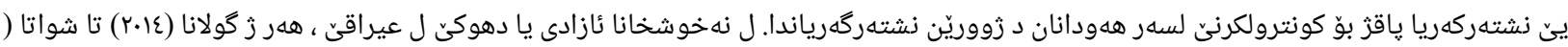

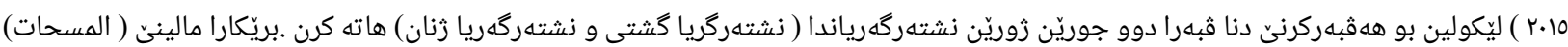

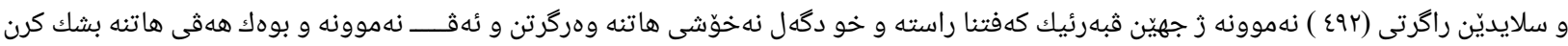

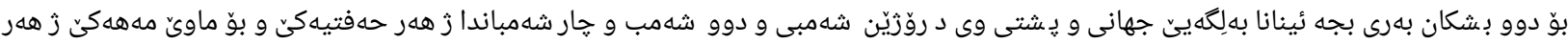

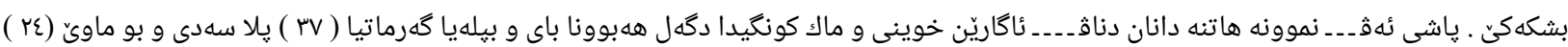

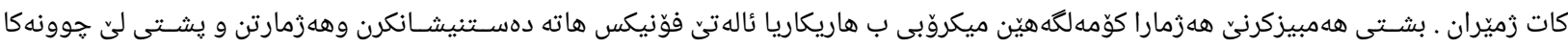

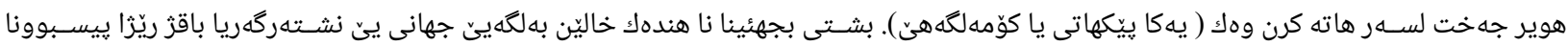

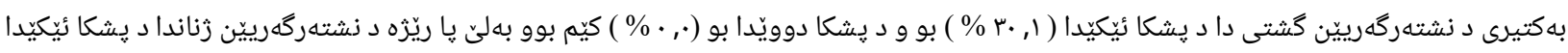

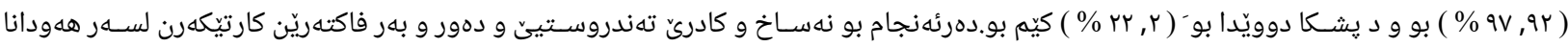

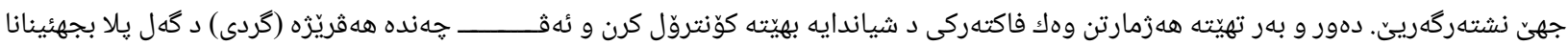
ييثهريّن جيهانى ييّن نشتهر نشكهريان.

خلاصة البحث: التهابات مو ضع الجراحة هي من اكثرالالتهابات المكت سبة من اله ستشفى. واجريت هذه الدرا سة لتقييم تطبيق الدليل القيا سي العالمي للجراحة النظيفة

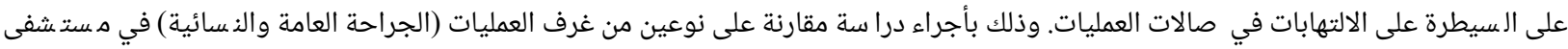

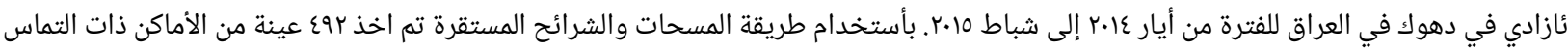

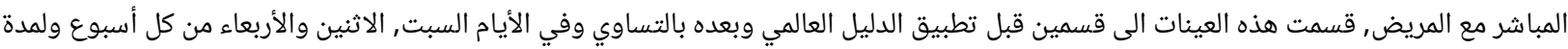

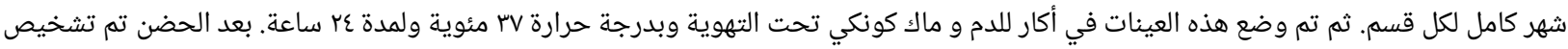

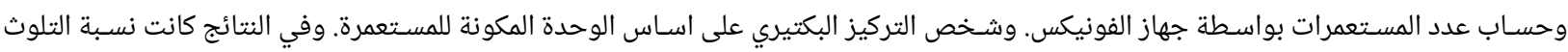

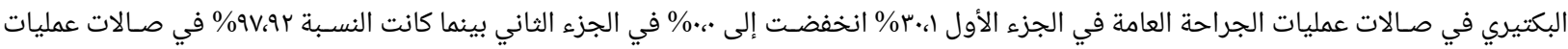

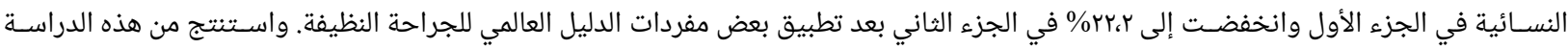

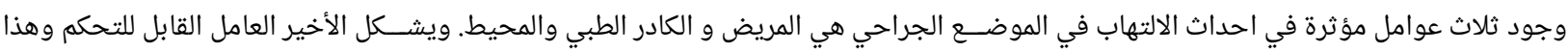

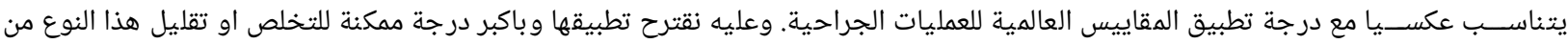

